Article

\title{
Is It Possible to Maintain the Quantity and Quality of Winter Wheat Grain by Replacing Part of the Mineral Nitrogen Dose by Growth Activators and Plant Growth-Promoting Rhizobacteria (PGPR)?
}

\author{
Arkadiusz Artyszak * (D) and Dariusz Gozdowski (D) \\ Institute of Agriculture, Warsaw University of Life Sciences-SGGW, Nowoursynowska 159, \\ 02-776 Warsaw, Poland; dariusz_gozdowski@sggw.edu.pl \\ * Correspondence: arkadiusz_artyszak@sggw.edu.pl; Tel.: +48-22-5932702
}

check for updates

Citation: Artyszak, A.; Gozdowski, D. Is It Possible to Maintain the Quantity and Quality of Winter Wheat Grain by Replacing Part of the Mineral Nitrogen Dose by Growth Activators and Plant Growth-Promoting Rhizobacteria (PGPR)? Sustainability 2021, 13, 5834. https://doi.org/10.3390/su13115834

Academic Editor: Luciano Cavani

Received: 7 April 2021

Accepted: 20 May 2021

Published: 22 May 2021

Publisher's Note: MDPI stays neutral with regard to jurisdictional claims in published maps and institutional affiliations.

Copyright: (c) 2021 by the authors. Licensee MDPI, Basel, Switzerland. This article is an open access article distributed under the terms and conditions of the Creative Commons Attribution (CC BY) license (https:// creativecommons.org/licenses/by/ $4.0 /)$.

\begin{abstract}
The introduction of the "Farm to Fork" strategy in the EU will require a significant reduction in mineral nitrogen fertilization, and therefore the introduction of innovative production technologies to prevent a decline in agricultural production. Studies carried out in several locations in Poland in 2016/17-2018/2019 tested the possibility of replacing 30\% of the dose of mineral nitrogen with growth activators alone, in combination with plant growth promoting rhizobacteria in the cultivation of winter wheat. It was confirmed that these two combinations allowed the obtention of a higher yield of grain by $13 \%$, compared to the full nitrogen dose. Simultaneously, the grain quality did not change significantly. In some locations, a decrease in the content of nitrates in the soil was observed, which may mean a greater uptake of this nutrient by plants and an increase in the content of some available macro- and micro-elements, mainly phosphorus, magnesium, zinc, copper and iron, and soil organic carbon. Introducing the studied treatment and limiting the fertilization with mineral nitrogen of wheat in Poland by only $30 \mathrm{~kg} \mathrm{ha}^{-1} \mathrm{~N}$ would save its consumption by 72 thousand $\mathrm{t}$ per year.
\end{abstract}

Keywords: growth activator; nitrogen; plant growth-promoting rhizobacteria; winter wheat

\section{Introduction}

Wheat is one of the most important crops in the world. In 2019 it was cultivated on 215.9 million ha, of which 26.0 million ha was in the EU (28). The dominant form is the winter form [1].

The size and technological quality of wheat grain is determined by many factors, including nitrogen fertilization [2]. Winter wheat uptakes $27 \mathrm{~kg}$ of nitrogen for the production of one tonne of grain with the appropriate secondary crop, and the maximum amount of nitrogen available in the cultivation of this plant in accordance by the law regulations in Poland is $200 \mathrm{~kg} \mathrm{~N} \mathrm{ha}^{-1}$ [3].

The introduction of restrictions on the size of nitrogen doses in the EU may result in a reduction in the size of grain yields and its quality. Hence, it is necessary to search for possibilities to increase the efficiency of fertilization with mineral nitrogen and to introduce modern technologies that could replace the not-applied amount of nitrogen. It is also important that they are safe for the environment.

One such method is use growth activators, whose beneficial effect was noted not only in the cultivation of wheat [4,5], but also in maize [6], coffee [7], soybean [8], legumes [4,9-11], potato [12] and sugar beet $[13,14]$.

Inoculating wheat seeds with nitrogen-fixing bacteria such as Azospirillum brasilense may be beneficial to the crop and reduce the need for $\mathrm{N}$ application [15].

Many studies confirm the beneficial effects of the use of plant growth-promoting rhizobacteria (PGPR) on grain yield of wheat [16-28]. 
The results of the research prove the possibility of limiting fertilization with mineral nitrogen in maize for grain and sugar beet by $30 \%$, by replacing it with the growth activators Penergetic-K and Penergetic-P (approved for organic farming in Switzerland, registered in Swiss Produkteregister Chemikalien under the numbers: 3727 and 3847) alone or together with the Azoter preparation (registered in Slovakian Central Controlling and Testing Institute of Agriculture at number OZP/431/2015) containing PGPR without limitation of yield $[6,14]$. There are no results of such studies in the cultivation of winter wheat.

The aim of the research was to find out whether, with a $30 \%$ reduction in the dose of mineral nitrogen and the use of the growth stimulants Penergetic-K and Penergetic-P alone or together with the Azoter preparation containing PGPR, it is possible to obtain the same yields of winter wheat grain of comparable quality, and how the tested products affect the soil reaction, the content of soil organic carbon and available macro- and microelements.

\section{Materials and Methods}

In years 2016/17-2018/2019, nine field experiments with winter wheat were conducted: four in season 2016/2017 (Sahryń, Pagów, Nowiny and Sławice); four in 2017/2018 (Sahryń, Pąów (two) and Nowiny); one in 2018/2019 (Sahryń) (Figure 1).

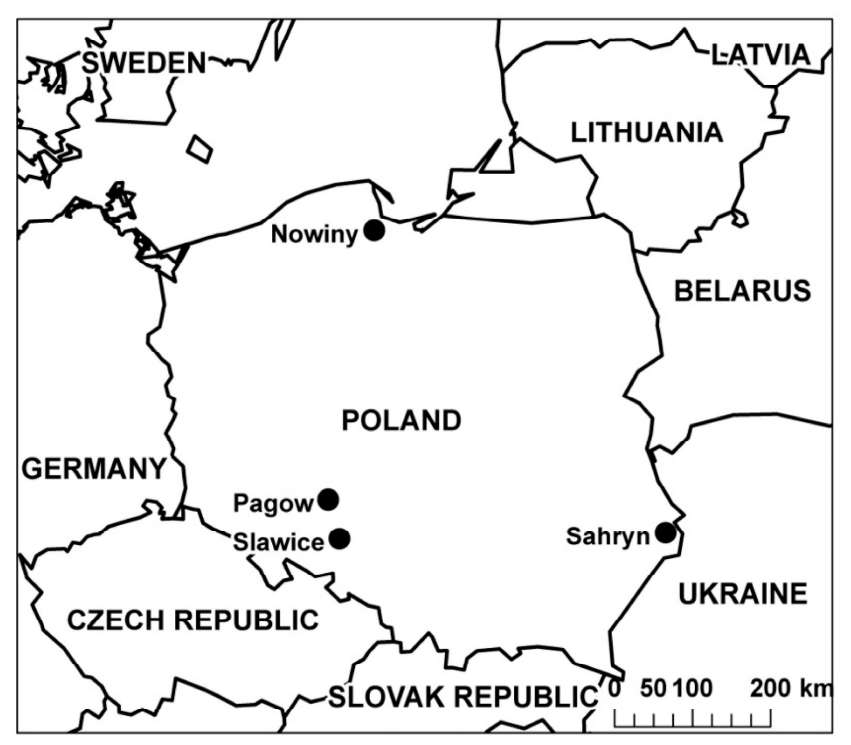

Figure 1. Locations of the field experiments.

The experiments were conducted on following soils: Sahryń-Calcic Chernozem (silty clay loam: clay-34\%, sand-14\%, silt-52\%); Pagów-Albic Podzols (sandy loam: clay-10\%, sand-55\%, silt-35\%); Nowiny_Endocalcaric Cambisol (sandy loam: clay11\%, sand-70\%, silt-19\%); Sławice-Albic Luvisols (sandy loam: clay-13\%, sand-55\%, silt-32\%) [29].

Soil samples were collected at two soil depths $(0-30 \mathrm{~cm}$ and $30-60 \mathrm{~cm})$ two times: immediately after harvesting the forecrop and after harvesting winter rapeseed. In each sampling, three subsamples per each plot were collected, i.e., one mixed composite sample per each treatment consisted of 12 subsamples ( 3 subsamples $\times 4$ plots). At District Chemical and Agricultural Stations in Warsaw-Wesoła, Opole and Gdańsk, soil parameters were evaluated $\left(\mathrm{pH}_{\mathrm{KCl}}\right)$ potentiometrically in $1 \mathrm{M} \mathrm{KCl}$ [30], content of soil organic carbon (SOC) based on Tiurin's method [31], nitrate nitrogen $\left(\mathrm{N}-\mathrm{NO}_{3}\right)$ and ammonium nitrogen $\left(\mathrm{NH}_{4}\right)$ extracted using $1 \%$ potassium sulfate and evaluated using continuous flow analysis method [32], available phosphorus (P) using Egner-Riehm DL method [33], available potassium (K) extracted using calcium lactate and evaluated using flame photometry method [34], available magnesium (Mg) extracted using calcium chloride and measured using flame atomic absorption spectrometry [35], available boron (B) using spec- 
trophotometric method [36], available copper $(\mathrm{Cu})$ extracted using hydrochloric acid and measured using flame atomic absorption spectrometry [37], available iron (Fe) extracted using hydrochloric acid and measured using flame atomic absorption spectrometry [38], available manganese $(\mathrm{Mn})$ extracted using hydrochloric acid and measured using flame atomic absorption spectrometry [39] and available zinc ( $\mathrm{Zn}$ ) extracted using hydrochloric acid and measured using flame atomic absorption spectrometry [40].

The $\mathrm{pH}$ of the soil before the experiments was in a range from 6.0 to 7.4 (layer $0-30 \mathrm{~cm}$ ) and from 5.0 to 7.4 (layer 30-60 cm) (Table S1, in Supplementary Materials). Content of SOC was in the range $0.78-4.98 \%(0-30 \mathrm{~cm})$ and $0.47-4.24 \%(30-60 \mathrm{~cm}), \mathrm{N}-\mathrm{NO}_{3}-$ $11.86-84.25 \mathrm{mg} \mathrm{kg}^{-1}$ and $6.90-74.48 \mathrm{mg} \mathrm{kg}^{-1}, \mathrm{~N}_{-} \mathrm{NH}_{4}-0.69-4.59 \mathrm{mg} \mathrm{kg}^{-1}$ and $<1.00$ $2.93 \mathrm{mg} \mathrm{kg}^{-1}$, mineral nitrogen (Nmin) 37-335 kg ha ${ }^{-1}$ and 36-295 kg ha ${ }^{-1}$ (assuming average soil bulk density in layer $0-60 \mathrm{~cm}$, for typical soil texture class which was estimated at $1.4-1.5 \mathrm{~g} \mathrm{~cm}^{-3}$ for soil in studied locations), $\mathrm{P}-12-1187 \mathrm{mg} \mathrm{kg}^{-1}$ and $7-176 \mathrm{mg} \mathrm{kg}^{-1}$, $\mathrm{K}-37-223 \mathrm{mg} \mathrm{kg}^{-1}$ and-21-217 $\mathrm{mg} \mathrm{kg}^{-1}, \mathrm{Mg}-47-129 \mathrm{mg} \mathrm{kg}^{-1}$ and 33-212 $\mathrm{mg} \mathrm{kg}^{-1}$. The content of available micronutrients was $\left(\mathrm{mg} \mathrm{kg}^{-1}\right)$ : $\mathrm{B}-0.2-5.8$ and $0.7-4.1, \mathrm{Cu}-1.8-$ 14.2 and 1.5-13.8, Fe-510-1757 and 520-2167, Mn-108-517 and 49-514, Zn-5.7-22.7 and 3.8-21.0.

In the study, the course of weather conditions was limited to the spring and summer growing season (March-July). The amount of rainfall in this period in the year 2017 was 259-406 mm, in 2018 197-419 $\mathrm{mm}$ and in 2019-265 mm (Figure 2).

The forecrop for winter wheat was in most cases winter rapeseed and, in some cases, maize for grain and sugar beet (Table S2, in Supplementary Materials). The doses of phosphorus in the experiments were $15-44 \mathrm{~kg} \mathrm{P} \mathrm{ha}^{-1}$, potassium $50-174 \mathrm{~kg} \mathrm{~K} \mathrm{ha}^{-1}$ and sulphur 3-32 $\mathrm{kg} \mathrm{S} \mathrm{ha}^{-1}$. Total phosphorus and potassium were used before sowing winter wheat. In spring, nitrogen was used in two or three doses: during the start of vegetation (Biologische Bundesanstalt, Bundessortenamt und Chemical Industry growth scale-BBCH 21-29), at the beginning of shooting (BBCH 31) and at the beginning of heading (BBCH 51). Sulphur was introduced with the first dose of nitrogen in the spring. Before sowing rapeseed, a small part of nitrogen and sulphur was supplied with compound fertilizers.

Depending on the location, the following mineral fertilizers were applied:

- Polifoska 6 (N in the form of ammonium-6\%, P in the form of mono- and diammonium phosphate- $-8.7 \%, \mathrm{~K}$ in the form of potassium chloride- $-24.9 \%, \mathrm{~S}$ in the form of sulphate-2.8\%);

- Polifoska 6 Tytan ( $\mathrm{N}$ in the ammonium form-6\%, $\mathrm{P}$ in the form of mono- and diammonium $-10.9 \%, \mathrm{~K}$ in the form of potassium chloride- $20.8 \%, \mathrm{~S}$ in the form of sulphate-2\%, $\mathrm{Fe}-0.5 \%, \mathrm{Zn}-0.05 \%+\mathrm{Ti})$;

- Amofoska 3,5-10-24 ( $\mathrm{N}$ in ammonium form-3.5\%, P-4.4\%, $\mathrm{K}-19.9 \%$ );

- Potassium salt ( $\mathrm{K}$ in the form of potassium chloride-49.8\%);

- Polidap-ammonium phosphate ( $\mathrm{N}$ in the ammonium form-18\%, $\mathrm{P}-20 \%, \mathrm{~S}-2 \%$ );

- Saletrosan 26 (N in the nitrate form-7\%, $\mathrm{N}$ in the ammonium form $19 \%, \mathrm{~S}$ in the form of sulphate-13\%);

- Saletrosan $30(\mathrm{~N}$ in the nitrate form-12\%, $\mathrm{N}$ in the ammonium form $18 \%, \mathrm{~S}$ in the form of sulphate-7\%);

- $\quad$ RSM 32: urea-ammonium nitrate solution ( $8 \% \mathrm{~N}$ in nitrate form, $8 \% \mathrm{~N}$ in ammonium form, $16 \% \mathrm{~N}$ in amide form);

- $\quad$ Urea ( $\mathrm{N}$ in the amide form-46\%);

- Ammonium nitrate 32\% ( $\mathrm{N}$ in the nitrate form-16\%, $\mathrm{N}$ in ammonium form-16\%);

- Ammonium nitrate $34 \%$ ( $\mathrm{N}$ in the nitrate form-17\%, $\mathrm{N}$ in ammonium form-17\%). 


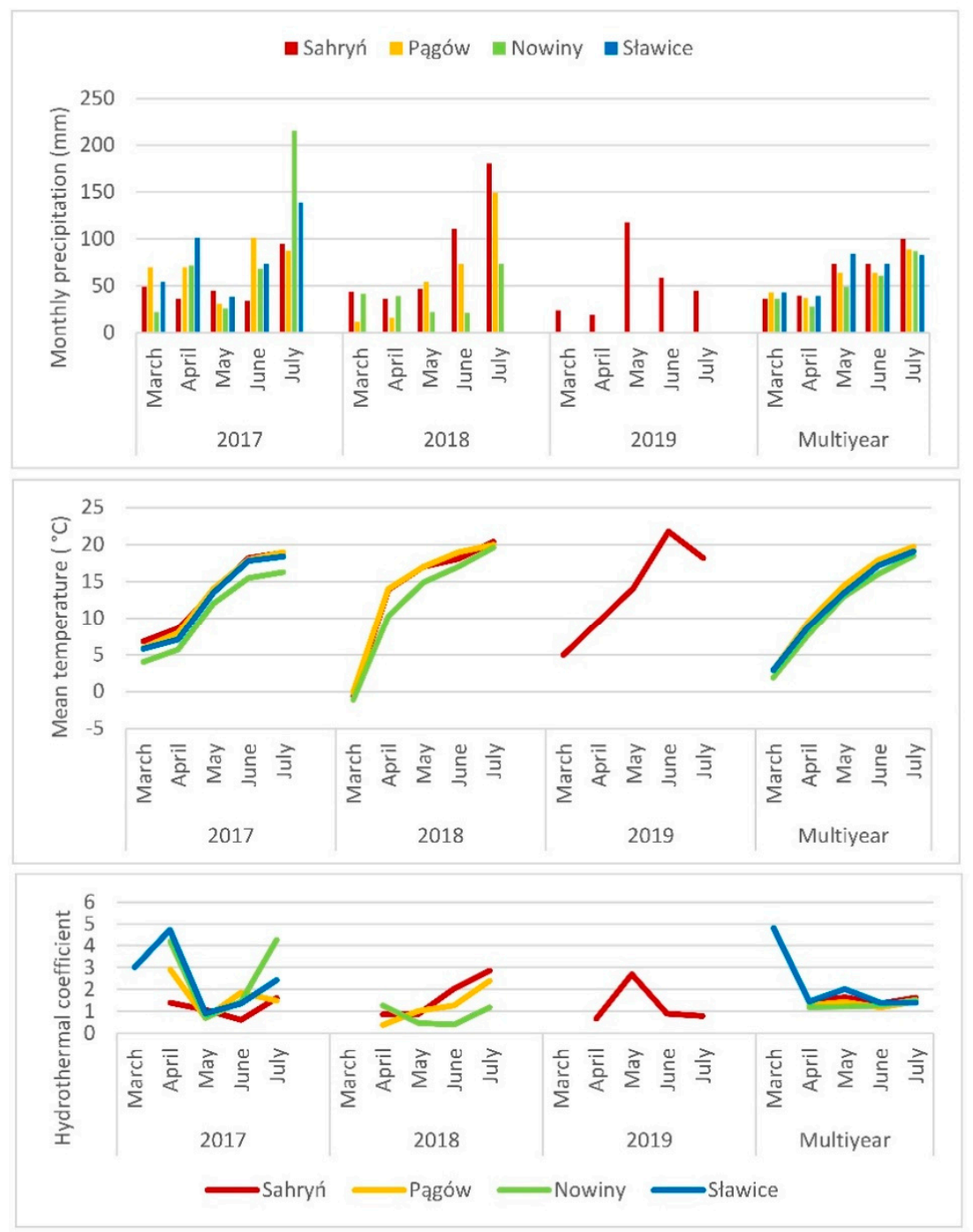

Figure 2. Weather conditions during the growing spring season of winter wheat (2017-2019). Precipitation: Sahryń (1991-2019), Pagów (1998-2019), Nowiny and Sławice (2001-2019). Temperature: Sahryń (2002-2019), Pagów, Nowiny and Sławice (2001-2019). Source: own study based on data from IMGW-PIB, "Pagro" farm, Strzyżów Sugar Factory.

Micronutrient foliar fertilizers containing copper, manganese and zinc were applied once in the fall and spring at the end of the wheat tillering phase (BBCH 29). Protection against weeds, diseases and pests and lodging (growth regulator) was carried out in accordance with the recommendations of the Institute of Plant Protection-National Research Institute in Poznań.

In the experiment, three treatments were studied:

0 control (full nitrogen fertilization dose depending on location-111-238 $\mathrm{kg} \mathrm{ha}^{-1} \mathrm{~N}$ ); 1 dose of mineral nitrogen lower by $30 \%$ in comparison to full dose before sowing and during vegetation (I the dose of nitrogen in spring is the same as in the control, II and III reduced dose -97 to $167 \mathrm{~kg} \mathrm{ha}^{-1} \mathrm{~N}$; Penergetic-K $\left(400 \mathrm{~g} \mathrm{ha}^{-1}\right)$-on the straw (winter rapeseed, maize) of the forecrop or leaves of sugar beet before it is mixed with the soil; Penergetic-K ( $\left.400 \mathrm{~g} \mathrm{ha}^{-1}\right)$ with the first pesticide spray in spring; Penergetic$\mathrm{P}\left(300 \mathrm{~g} \mathrm{ha}^{-1}\right)$ with a second pesticide spray in spring; Penergetic-P $\left(300 \mathrm{~g} \mathrm{ha}^{-1}\right)$ 3 weeks later;

2 dose of mineral nitrogen lower by $30 \%$ in comparison to full dose before sowing and during vegetation (I the nitrogen dose in spring is the same as in the control, II and III reduced dose)—97 to $167 \mathrm{~kg} \mathrm{ha}^{-1} \mathrm{~N}$; Penergetic-K $\left(400 \mathrm{~g} \mathrm{ha}^{-1}\right)+$ 
Azoter (10 $\left.\mathrm{dm}^{3} \mathrm{ha}^{-1}\right)$ - on the straw (winter rapeseed, maize) of the forecrop or sugar beet leaves before it is mixed with the soil; Penergetic-K $\left(400 \mathrm{~g} \mathrm{ha}^{-1}\right)+$ Azoter $\left(10 \mathrm{dm}^{3} \mathrm{ha}^{-1}\right)$ with the first pesticide spray in spring; Penergetic-P $\left(300 \mathrm{~g} \mathrm{ha}^{-1}\right)$ with the second pesticide spray in spring; Penergetic-P (300 $\left.\mathrm{g} \mathrm{dm}^{3} \mathrm{ha}^{-1}\right)$-3 weeks later.

Penergetic-K and Penergetic-P are growth activators, the compositions of which are reserved by the manufacturer. The product contains no other chemical substances. Penergetic International AG Company produces Penergetic-P and K from bentonite clays subjected to the application of electric and magnetic fields. Azoter is a preparation which contains plant growth-promoting rhizobacteria (PGPR) produced by Azoter Trading s.r.o. The manufacturer states that the $\mathrm{pH}$ of the preparation is 5.8-8.5, a total number of living microorganisms (Azotobacter chroococcum, Azospirillum brasilense, Bacillus megaterium) is at least $4 \times 10^{9}$ colony-forming units $(\mathrm{CFU}) \mathrm{cm}^{-3}$. Both products were selected for testing due to their innovation and environmental safety. The amount of water in each treatment was $250 \mathrm{dm}^{3} \mathrm{ha}^{-1}$. Number of replications: 4, and total number of plots: 12 in each site.

Before harvest, plants were cut from a representative area of $15 \mathrm{~m}^{2}(3 \times 5 \mathrm{~m})$ from each plot. The number of spikes and non-productive shoots was counted. Ten plants were randomly selected from each sample and plant height and number of grain per spike were determined. Then, all the plants were threshed, the grain were cleaned of impurities and the grain yield and the straw yield were weighed.

The quality traits, such as test weight, grain protein content, Zeleny sedimentation value and wet gluten content were determined by near-infrared spectroscopy using an InfratecTM 1241 Grain Analyzer (FOSS, Hillerød, Denmark) which measures the reflectance in the 400-2498 nm wavelength, after calibration against quality traits determined by AACC methods [41]. The Hagberg falling number was determined using the Falling Number Test Apparatus, type SWD [42]. Moreover, grain fractions were separated [43] and the weight of 1000 grains was measured using standard procedures [44]. Grain yield was determined based on a standard moisture of $14 \%$.

The following traits were measured in the experiments:

1. Grain yield at moisture $14 \%, \mathrm{t} \mathrm{ha}^{-1}$;

2. Grain moisture, \%;

3. Yield of straw, $\mathrm{t} \mathrm{ha}^{-1}$;

4. Spike density, pcs. $\mathrm{m}^{-2}$;

5. Number of non-productive shoots, pcs. $\mathrm{m}^{-2}$;

6. Total number of shoots, pcs. $\mathrm{m}^{-2}$;

7. Weight of 1000 grains $\left(14 \% \mathrm{H}_{2} \mathrm{O}\right), \mathrm{g}$;

8. Protein content, \% d.m.;

9. Content of wet gluten, \% d.m.;

10. Grain uniformity (fractions separated at sieves $2.5 \times 25 \mathrm{~mm}$ ), \%;

11. Hagberg falling number, s;

12. Zeleny sedimentation value (SDS), $\mathrm{ml}$;

13. Height of plants, $\mathrm{cm}$;

14. Number of grains per spike, pcs.

The data were analyzed using analysis of variance (ANOVA) and multiple comparisons of mean using Tukey's honestly significant difference (HSD) procedure. Two-way ANOVA was used for the analyses where factors were treatment and environment. Environment was treated as one factor which is a combination of location and year, i.e., effects of year and locations were not evaluated separately in the analysis. For the analyses for year 2019, one-way ANOVA was applied due to lack of the second factor (environment). Assumptions of ANOVA were checked based on residuals of the model. Homogeneity of variances were tested using Levene's test and normality was tested using the Shapiro-Wilk test. The significance level for all analyses was set at 0.05 . The analyses were performed using Statistica 13 software (TIBCO Software Inc., Palo Alto, CA, USA). Descriptive statistics, 
including minimum, maximum, standard deviation (SD) and coefficient of variation (CV), were calculated.

\section{Results}

Treatment number 1 caused a significant increase in the grain yield (by 13.2\%), 1000 grain weight (by 6.1\%), grain uniformity (by 1.8\%), falling number (by 3.9\%), plant height (by 3.8\%) and the number of grains in ears (by $8.9 \%$ ), and a significant reduction in the density of non-productive shoots (by 23.0\%) and the value of Zeleny's sedimentation value (by $1.8 \%$ ) compared to treatment number 0 (Table 1, Figure 3 ).

Table 1. Influence of Penergetic activators (Penergetic International AG, Romanshorn, Switzerland) and Azoter bacterial preparation (Azoter Trading, Bratislava, Slovakia) on yield and traits of winter wheat plants (2016/17-2018/2019) and effects of treatment and environment (location $\times$ year) and their interaction. For the treatments, marginal means for all experiments together are presented.

\begin{tabular}{|c|c|c|c|c|c|c|}
\hline \multirow[b]{2}{*}{ Trait } & \multicolumn{3}{|c|}{ Treatment } & \multicolumn{3}{|c|}{$p$-Value Based on ANOVA } \\
\hline & 0 & 1 & 2 & Treat-Ment (T) & $\begin{array}{l}\text { Environ-Ment } \\
(\text { E: Year } \times \text { Location) }\end{array}$ & $\begin{array}{l}\text { Inter-Action: } \\
\mathrm{T} \times \mathrm{E}\end{array}$ \\
\hline Grain yield at moisture $14 \%, \mathrm{t} \mathrm{ha}^{-1}$ & $7.30 \mathrm{a}^{*}$ & $8.26 \mathrm{~b}$ & $8.30 \mathrm{~b}$ & $<0.001$ & $<0.001$ & 0.128 \\
\hline Grain moisture, \% & $12.21 \mathrm{a}$ & $12.23 \mathrm{a}$ & $12.27 \mathrm{a}$ & $<0.001$ & 0.630 & 0.001 \\
\hline Yield of straw, $\mathrm{t} \mathrm{ha}^{-1}$ & $5.57 \mathrm{a}$ & $6.01 \mathrm{ab}$ & $6.37 \mathrm{~b}$ & $<0.001$ & 0.012 & 0.184 \\
\hline Spike density, pcs. $\mathrm{m}^{-2}$ & $627.25 \mathrm{a}$ & $641.44 \mathrm{a}$ & $630.06 \mathrm{a}$ & $<0.001$ & 0.384 & 0.035 \\
\hline Number of non-productive shoots, pcs. $\mathrm{m}^{-2}$ & $55.50 \mathrm{~b}$ & $42.72 \mathrm{a}$ & $46.11 \mathrm{a}$ & $<0.001$ & 0.008 & 0.160 \\
\hline Total number of shoots, pcs. $\mathrm{m}^{-2}$ & $682.75 \mathrm{a}$ & $683.89 \mathrm{a}$ & $676.17 \mathrm{a}$ & $<0.001$ & 0.772 & 0.144 \\
\hline Weight of 1000 grains $\left(14 \% \mathrm{H}_{2} \mathrm{O}\right), \mathrm{g}$ & $41.87 \mathrm{a}$ & $44.42 \mathrm{~b}$ & $44.14 \mathrm{~b}$ & $<0.001$ & $<0.001$ & 0.043 \\
\hline Protein content, \% d.m. & $14.57 \mathrm{~b}$ & $14.57 \mathrm{~b}$ & $14.37 \mathrm{a}$ & $<0.001$ & 0.004 & $<0.001$ \\
\hline Content of wet gluten, \% d.m. & $29.92 \mathrm{~b}$ & $29.77 \mathrm{ab}$ & $29.51 \mathrm{a}$ & $<0.001$ & 0.026 & $<0.001$ \\
\hline $\begin{array}{l}\text { Grain uniformity (fractions separated at } \\
\text { sieves } 2.5 \times 25 \mathrm{~mm} \text { ) } \%\end{array}$ & $79.83 \mathrm{a}$ & $81.29 \mathrm{~b}$ & $82.21 \mathrm{c}$ & $<0.001$ & $<0.001$ & $<0.001$ \\
\hline Hagberg falling number, $\mathrm{s}$ & $308.72 \mathrm{a}$ & $320.67 b$ & $322.22 \mathrm{~b}$ & $<0.001$ & 0.005 & 0.002 \\
\hline Zeleny sedimentation value (SDS), $\mathrm{mL}$ & $48.60 \mathrm{~b}$ & $47.71 \mathrm{a}$ & $48.92 \mathrm{~b}$ & $<0.001$ & 0.020 & $<0.001$ \\
\hline Height of plants, $\mathrm{cm}$ & $67.14 \mathrm{a}$ & $69.67 \mathrm{~b}$ & $71.93 \mathrm{c}$ & $<0.001$ & $<0.001$ & $<0.001$ \\
\hline Number of grains per spike, pcs. & $42.52 \mathrm{a}$ & $46.30 \mathrm{~b}$ & $46.18 \mathrm{~b}$ & $<0.001$ & $<0.001$ & 0.009 \\
\hline
\end{tabular}

* The same letters within rows indicate lack of significant differences between means at $\alpha=0.05$.

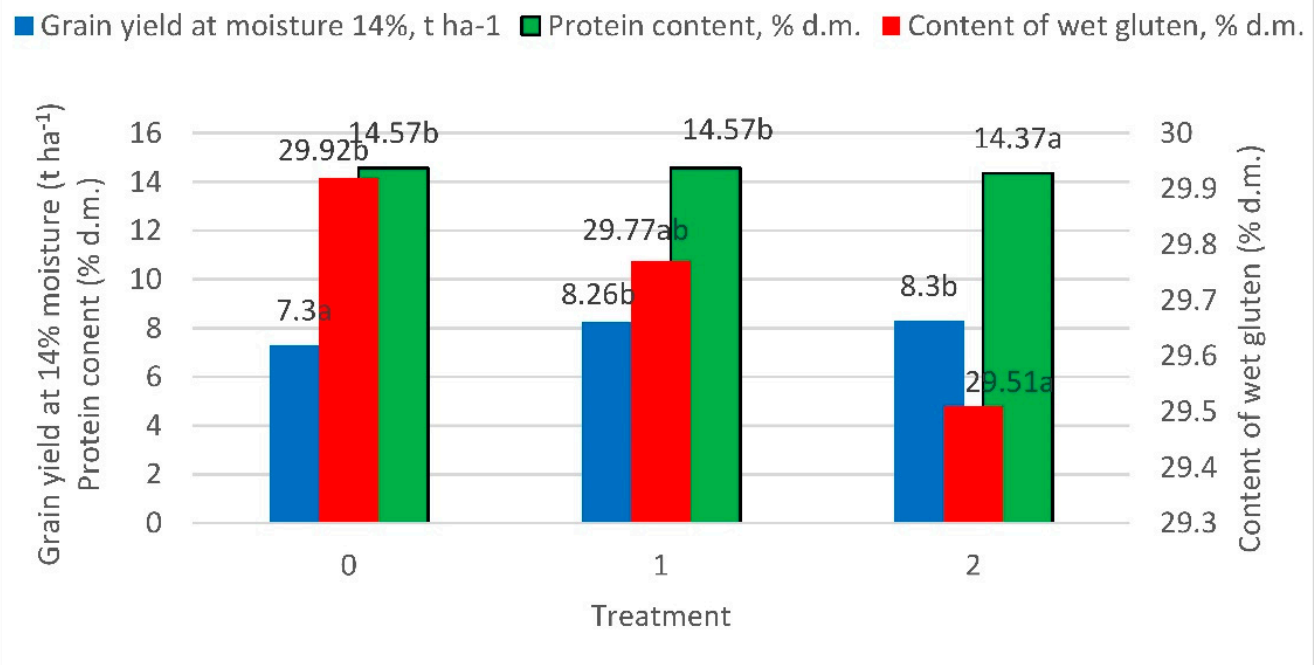

Figure 3. Means of grain yield, protein content and wet gluten of treatments of winter wheat in years 2017-2019. For the treatments, marginal means for all experiments together are presented (different letters indicate significant differences at 0.05 probability level). 
Among the examined traits, the greatest variability was found for the density of nonproductive shoots $(\mathrm{CV}=77.9 \%)$, and the smallest for protein content in grain $(\mathrm{CV}=7.8 \%)$ (Table 2).

Table 2. Descriptive statistics for all experiments with winter wheat (2017-2019).

\begin{tabular}{|c|c|c|c|c|c|}
\hline Trait & Mean & Minimum & Maximum & $\begin{array}{l}\text { Standard } \\
\text { Deviation (SD) }\end{array}$ & $\begin{array}{l}\text { Coefficient of } \\
\text { Variation }(\mathrm{CV}), \%\end{array}$ \\
\hline Grain yield at moisture $14 \%, \mathrm{t} \mathrm{ha}^{-1}$ & 7.95 & 2.62 & 11.48 & 1.76 & 22.19 \\
\hline Grain moisture, \% & 12.24 & 9.80 & 15.00 & 1.55 & 12.65 \\
\hline Yield of straw, $\mathrm{t}$ ha ${ }^{-1}$ & 5.99 & 1.84 & 14.72 & 2.58 & 43.17 \\
\hline Spike density, pcs. $\mathrm{m}^{-2}$ & 632.92 & 393.00 & 885.00 & 130.19 & 20.57 \\
\hline Number of non-productive shoots, pcs. $\mathrm{m}^{-2}$ & 48.11 & 3.00 & 180.00 & 37.47 & 77.88 \\
\hline Total number of shoots, pcs. $\mathrm{m}^{-2}$ & 680.94 & 431.00 & 977.00 & 150.23 & 22.06 \\
\hline Weight of 1000 grains $\left(14 \% \mathrm{H}_{2} \mathrm{O}\right), \mathrm{g}$ & 43.48 & 24.40 & 54.30 & 6.64 & 15.26 \\
\hline Protein content, \% d.m. & 14.50 & 12.20 & 16.80 & 1.14 & 7.83 \\
\hline Content of wet gluten, \% d.m. & 29.73 & 20.80 & 36.90 & 4.03 & 13.55 \\
\hline $\begin{array}{l}\text { Grain uniformity (fractions separated at } \\
\text { sieves } 2.5 \times 25 \mathrm{~mm} \text { ) } \%\end{array}$ & 81.11 & 66.00 & 91.80 & 6.54 & 8.07 \\
\hline Hagberg falling number, s & 317.20 & 241.00 & 390.00 & 35.15 & 11.08 \\
\hline Zeleny sedimentation value (SDS), $\mathrm{mL}$ & 48.41 & 21.00 & 71.00 & 16.08 & 33.22 \\
\hline Height of plants, $\mathrm{cm}$ & 69.58 & 48.50 & 94.50 & 11.85 & 17.04 \\
\hline Number of grains per spike, pcs. & 45.00 & 31.00 & 64.80 & 7.67 & 17.05 \\
\hline
\end{tabular}

Treatment number 2 caused a significant increase in grain yield (by 13.7\%), straw yield (by $14.4 \%$ ), 1000 grain weight (by $5.4 \%$ ), grain uniformity (by $3.0 \%$ ), falling number (by $4.4 \%$ ), plant height (by 7.1\%) and the number of grains per spike (by $8.6 \%$ ), as well as a significant reduction in the number of non-productive shoots (by $16.9 \%$ ), the protein content in the grain (by 1.4\%) and the content of gluten (by 1.4\%) compared to treatment number 0 .

Treatment number 2 was characterized by a significantly higher grain uniformity (by $1.1 \%$ ), the value of Zeleny sedimentation value (by 2.1\%) and plant height (by 3.2\%), and significantly lower protein content in the grain (by $1.4 \%$ ) compared to treatment number 1.

The increase in grain yield obtained in treatments number 1 and number 2 resulted from an increase in the number and size of grains per spike in relation to treatment number 0 .

All $p$-values based on ANOVA for effect of treatment (treatment) were significant at $p<0.001$. Moreover, most of interaction between environment and treatment was significant, which means that the effect of the treatments can be modified by soil and weather conditions.

Significant differences between means within each year were observed for grain yield for year 2017 and 2018 (Figure 4). Spike density was similar for the treatments in all years, but the number of grains per spike was significantly lower in control treatment in comparison to treatments with PGPR (treatments 1 and 2) in years 2018 and 2019. The weight of 1000 grains was significantly lower in all years for control treatment in comparison to other studied treatments. Significant differences between treatments for protein content and wet gluten were observed in years 2018 and 2019, but these results were opposite, because the lowest means for both traits were observed for treatment 2 in year 2018, while in year 2019 the lowest means were observed for control (treatment 0). 


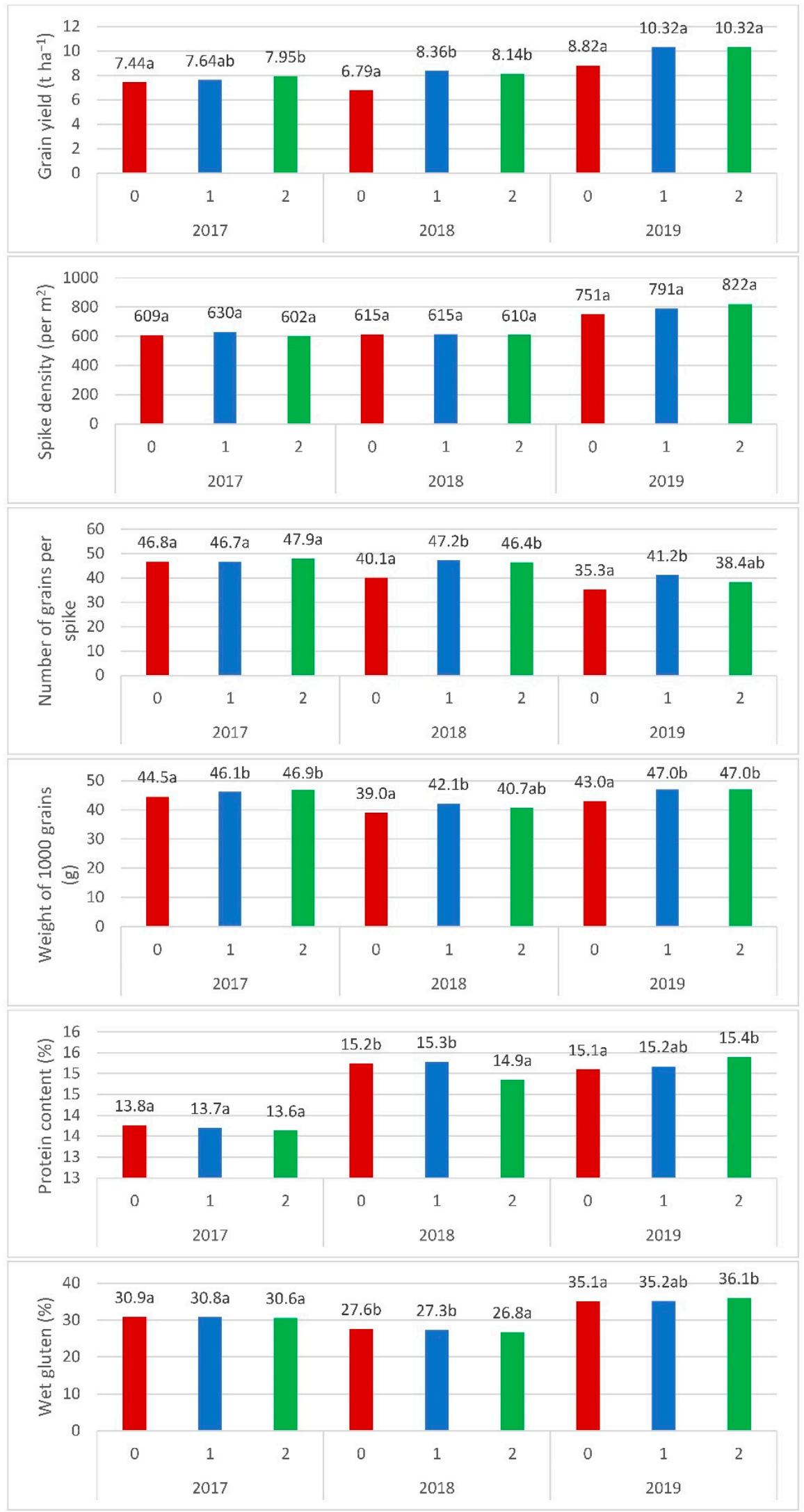

Figure 4. Means of grain yield, protein content and wet gluten for the treatments (0,1 and 2) of winter wheat in each year of the study and comparisons of means within each year (different letters indicate significant differences at 0.05 probability level). For the treatments, marginal means are presented. 


\section{Discussion}

In the conducted experiments, a reduction in the content of $\mathrm{N}^{-\mathrm{NO}_{3}}$ and mineral $\mathrm{N}$, and an increase in the content of SOC and available $\mathrm{Mg}, \mathrm{Zn}, \mathrm{Cu}$ and $\mathrm{Fe}$ in the soil was found in combinations number 1 and number 2; however, because of a lack of replications, the results were not compared based on statistical tests. The same experimental combinations used in beet cultivation caused an increase in the content of $\mathrm{N}-\mathrm{NO}_{3}, \mathrm{~N}-\mathrm{NH}_{4}, \mathrm{Nmin}$, $\mathrm{P}, \mathrm{K}$, and $\mathrm{Mg}$ in the soil compared to the control treatment 0 [14]. In turn, in the maize, an increase in the content of available $\mathrm{Mg}, \mathrm{Fe}, \mathrm{P}, \mathrm{K}$ and $\mathrm{Zn}, \mathrm{SOC}$ and soil $\mathrm{pH}$ compared to the control was observed [6]. These variations may be caused by many factors, including the timing of sampling for post-harvest testing of the crop. In the case of sugar beet and grain maize, this was in September-November, while in case of wheat-July. Biopreparations help to preserve the SOC content or even increase it in deeper soil layers at 10-20 cm depth despite unfavorable meteorological conditions, as evidenced by the results of previous studies [28].

Combinations number 1 and number 2 allowed the obtention of an increase in grain yield by $13-14 \%$ with a $30 \%$ limited fertilization with mineral nitrogen. These results are similar to earlier studies in which inoculation of wheat was applied $[28,45,46]$. Only in some studies did the application of PGPR have no effect on the yield of wheat [47].

Regardless of the inoculation technique, half the dose of $\mathrm{N}$ fertilizer combined with A. brasilense in liquid formulation provided significantly superior results in agronomic performance compared to the treatment in which only the half the dose of $\mathrm{N}$ fertilizer was used. However, it is inferred that seed inoculation with $A$. brasilense associated with full nitrogen fertilization showed the highest increase in wheat development and grain yield [18].

The positive influence of $\mathrm{N}$ side-dress fertilization combined with the application of Azospirillum brasilense seed inoculation in wheat was examined [22]. the study proved an average yield increase of $36.8 \%$ and $13.5 \%$ when the inoculation was associated with $\mathrm{N}$ application rates of 70 and $140 \mathrm{~kg} \mathrm{ha}^{-1}$, respectively. The inoculation of seed with Azospirillum brasilense together with the application of $140 \mathrm{~kg} \mathrm{~N}^{-1}$ caused an increase in wheat grain yield $[21,26]$. Inoculation with $A$. brasilense in treatment with the application of 100 and $150 \mathrm{~kg} \mathrm{~N} \mathrm{ha}^{-1}$ caused an increase in grain yield by $19.6 \%$ and $18.8 \%$, respectively [27]. It is inferred that the A. brasilense is efficient in performing partial nitrogen fixation supplemented by nitrogen fertilization; yield is positively influenced by nitrogen fertilization associated with inoculation, regardless of the type of inoculants [17].

In wheat crop management, $A$. brasilense increased yields by $13-18 \%$ and $31 \%$, which was explained by general increases in uptake of several macro and micronutrients and not specifically attributed to biological nitrogen fixation [16]. In other studies, an average increase in nitrogen use efficiency (NUE) by $51.2 \%$ was observed when the inoculation with $A$. brasilense was associated with $\mathrm{N}$ application rates varying between 50 and $200 \mathrm{~kg} \mathrm{ha}^{-1}$ [20].

The study showed positive improvements in wheat growth production parameters, NUE and grain yield as a function of inoculation of Azospirillum brasilense associated with $\mathrm{N}$ rates. Inoculation can complement and optimize $\mathrm{N}$ fertilization, even with high $\mathrm{N}$ application rates [25]. Co-inoculation of seeds Azospirillum brasilense and Rhizobium pisi significantly increased wheat grain yield, the number of grains per plant and 1000-grain weight by $36 \%, 11 \%$ and $17 \%$, respectively, compared to non-inoculated control [23].

It was concluded that the combined application of rhizobacteria and cytokinins could play a significant role in improving wheat yield and also alleviating stress under drought condition [24].

The increase in plant height and the number of grains per spike after application was observed in the research with the growth activator and preparation which contains PGPR, which confirms results of the previous research in which the effect of Azospirillum brasilense promoted an increase in plant height and number of grains per spike [48]. 
In some research, the inoculation with Azospirillum brasilense alone did not affect production components and grain yield, although it increased the $\mathrm{N}$ content in wheat straw. The inoculation with $A$. brasilense, in addition to the application of $140 \mathrm{~kg} \mathrm{ha}^{-1} \mathrm{~N}$, provides the highest grain yield of irrigated wheat crops after corn [49]. It is still unknown exactly how PGPR stimulates plant growth. It is assumed that several mechanisms are involved in this, including the solubilization of phosphorus, potassium and zinc [46,50-55]. Increased tolerance of wheat plants to drought stress [56-58], biotic stress $[59,60]$ and salt stress $[58,61]$ is also important. PGPRs also improve wheat growth in fields with soils contaminated with heavy metals, for example mercury [62]. An improvement in the germination of wheat grain was also observed [63].

Our research results were obtained in various locations: in the north, south-west and south-east of Poland. Therefore, it can be assumed with high probability that similar results with the use of growth activators and bacterial preparations can be obtained in neighboring countries with similar weather and soil conditions: in the eastern part of Germany, the Czech Republic, Slovakia, western Ukraine and western Belarus, Lithuania and the Kaliningrad Oblast of Russia. In other European countries, due to the greater differences in soil and climatic conditions in comparison to Poland, the obtained results may be different.

\section{Conclusions}

The use growth activators Penergetic with the Azoter bacterial preparation containing plant growth-promoting rhizobacteria in conditions of fertilization with mineral nitrogen reduced by $30 \%$ allows for an increased wheat grain yield by approx. $13 \%$, compared to the treatment with a full dose of nitrogen (Figure 5). The quality of the wheat grain does not change significantly.

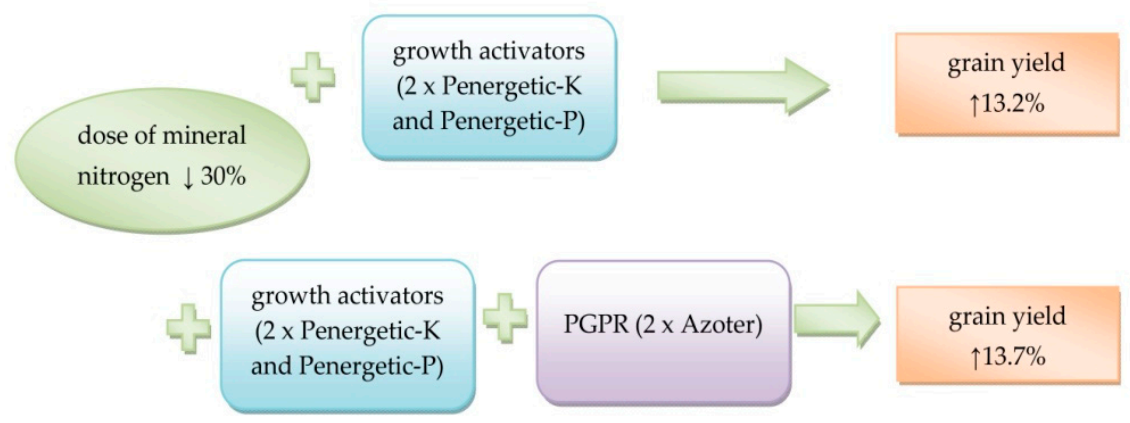

Figure 5. Effect of the application of the reduced dose of mineral nitrogen, growth activators and PGPR on the grain yield of winter wheat-summary.

With the wheat cultivation area in Poland amounting to 2.4 million ha, limiting the fertilization with mineral nitrogen only by $30 \mathrm{~kg}^{-1} \mathrm{~N}$ would save its consumption by 72 thousand t per year. This would certainly be beneficial for the environment. The tested solution should help in the implementation of the "Farm to Fork" strategy in EU agriculture. The introduction of environmentally friendly products containing PGPR as a common practice is impossible without the financial support of the state, as well as mass awareness of consumers and farmers about their advantages.

Supplementary Materials: The following are available online at https://www.mdpi.com/article/10 $.3390 /$ su13115834/s1, Table S1: Soil conditions before establishing an experiment with winter rapeseed (2016-2018), Table S2: Characteristics of winter wheat production technology in the experiment (2016/2017-2018/2019), Table S3: Soil conditions after the harvest winter wheat (2017-2019).

Author Contributions: Conceptualization, A.A.; formal analysis, A.A.; investigation, A.A.; methodology, A.A.; supervision, A.A.; visualization, D.G.; writing—original draft, A.A. and D.G.; writingreview \& editing, A.A. and D.G. Both authors have read and agreed to the published version of the manuscript. 
Funding: This research received no external funding.

Institutional Review Board Statement: Not applicable.

Informed Consent Statement: Not applicable.

Data Availability Statement: The data presented in this study are available on request from the corresponding author. The data are not publicly available due to ongoing unpublished research.

Conflicts of Interest: The authors declare no conflict of interest.

\section{References}

1. FAO. Food and Agriculture Data. Available online: http://www.fao.org/faostat/en/\#data/QC (accessed on 7 April 2021).

2. Golba, J.; Rozbicki, J.; Gozdowski, D.; Sas, D.; Mądry, W.; Piechociński, M.; Murzyńska, L.; Studnicki, M.; Derejko, A. Adjusting yield components under different levels of $\mathrm{N}$ applications in winter wheat. Int. J. Plant Prod. 2013, 7, 139-150. [CrossRef]

3. Polish Council of Ministers. Regulation of the Polish Council of Ministers on the Adoption of the Action Program to Reduce Water Pollution with Nitrates from Agricultural Sources and to Prevent Further Pollution. Available online: https:/ /isap.sejm. gov.pl/isap.nsf/DocDetails.xsp?id=WDU20200000243 (accessed on 21 May 2021).

4. Kadziuliene, Z.; Feiziene, D.; Leistrumaite, A.; Semaskiene, R. Peculiarities of some legumes and cereals under organic farming system. NJF Rep. 2005, 1, 103-106.

5. Pekarskas, J.; Vilkenyte, L.; Sileikiene, D.; Cesoniene, L.; Makarenko, N. Effect of organic nitrogen fertilizers Provita and fermentator Penergetic-K winter wheat and on soil quality. In Proceedings of the 8th International Conference, Environmental Engineering, Vilnius, Lithuania, 19-20 May 2011; pp. 248-254.

6. Artyszak, A.; Gozdowski, D. Is it possible to replace part of the mineral nitrogen dose in maize for grain by using growth activators and plant growth-promoting rhizobacteria? Agronomy 2020, 10, 1647. [CrossRef]

7. Franco Junior, K.S.; Terra, A.B.C.; Teruel, T.R.; Mantovani, J.R.; Florentino, L.A. Effect of cover crops and bioactivators in coffee and chemical properties of soil. Coffee Sci. Lavras 2018, 13, 559-567.

8. De Souza, A.A.; de Almeida, F.Z.; Alberton, O. Growth and yield of soybean with Penergetic application. Sci. Agrar. 2017, 18, 95-98.

9. Brito, O.R.; Dequech, F.K.; Brito, R.M. Use of Penergetic products P and K in the snap bean production. Annu. Rep. 2012, 55, 279-280.

10. Jankauskienè, J.; Survilienè, E. Influence of growth regulators on seed germination energy and biometrical parameters of vegetables Scientific works of the Lithuanian Institute of Horticulture and Lithuanian University of Agriculture. Sodininkyste Ir Daržininkystè 2009, 28, 69-77.

11. Nascente, A.S.; Cobucci, T. Phosphate fertilization in the soil and Penergetic application in the grain yield of common bean. Soils Embrace Life and Universe. In Proceedings of the 20th World Congress of Soil Science, Jeju, Korea, 8-13 June 2014.

12. Jakiene, E.; Venskutonis, V.; Mickevicius, V. The effect of additional fertilization with liquid complex fertilizers and growth regulators on potato productivity. Scientific works of the Lithuanian Institute of Horticulture and Lithuanian University of Agriculture. Sodininkystè Ir Daržininkystè 2008, 27, 259-267.

13. Jakiene, E.; Venskutonis, V.; Liakas, V. Fertilization of sugar beet root with ecological fertilizers. Agron. Res. 2009, 7, $269-276$.

14. Artyszak, A.; Gozdowski, D. The effect of growth activators and plant growth-promoting rhizobacteria (PGPR) on the soil properties, root yield, and technological quality of sugar beet. Agronomy 2020, 10, 1262. [CrossRef]

15. Nunes, P.H.M.P.; Aquino, L.A.; dos Santos, L.P.D.; Xavier, F.O.; Dezordi, L.R.; Assunção, N.S. Yield of the irrigated wheat crop subjected to nitrogen application and to inoculation with Azospirillum brasilense. Rev. Bras. Ciênc. Sol. 2015, 39, 174-182. [CrossRef]

16. Hungria, M.; Campo, R.J.; Souza, E.M.; Pedrosa, F.O. Inoculation with selected strains of Azospirillum brasilense and A. lipoferum improves yields of maize and wheat in Brazil. Plant Soil 2010, 331, 413-425. [CrossRef]

17. Piccinin, G.G.; Braccini, A.L.; Dan, L.G.M.; Scapim, C.A.; Ricci, T.T.; Bazo, G.L. Efficiency of seed inoculation with Azospirillum brasilense on agronomic characteristics and yield of wheat. Industr. Crops Prod. 2013, 43, 393-397. [CrossRef]

18. Pereira, L.C.; Piana, S.C.; Braccini, A.L.; Garcia, M.M.; Ferri, G.C.; Felber, P.H.; Marteli, D.C.V.; Dametto, P.B.I. Wheat (Triticum aestivum) yield response to different inoculation techniques of Azospirillum brasilense. Rev. Ciênc. Agrár. 2017, 40, 105-113. [CrossRef]

19. Salvo, L.P.; Ferrando, L.; Fernandéz-Scavino, A.; Salamone, I.E.G. Microorganisms reveal what plants do not: Wheat growth and rhizosphere microbial communities after Azospirillum brasilense inoculation and nitrogen fertilization under field conditions. Plant Soil 2018, 424, 405-417. [CrossRef]

20. Galindo, F.S.; Filho, M.C.M.T.; Buzetti, S.; Rodrigues, W.L.; Santini, J.M.K.; Alves, C.J. Nitrogen fertilisation efficiency and wheat grain yield affected by nitrogen doses and sources associated with Azospirillum brasilense. Acta Agr. Scand. Sec. B Soil Plant Sci. 2019, 69, 606-617. [CrossRef]

21. Galindo, F.S.; Filho, M.C.M.T.; Buzetti, S.; Santini, J.M.K.; Montanari, R.; Freitas, L.A.; Rodrigues, W.L. Micronutrient accumulation with Azospirillum Brasilense associated with nitrogen fertilization management in wheat. Commun. Soil Sci. Plan. 2019, $2429-2441$. [CrossRef]

22. Munareto, J.D.; Martin, T.N.; Fipke, G.M.; Cunha, V.S.; da Rosa, G.B. Nitrogen management alternatives using Azospirillum brasilense in wheat. Pesq. Agropec. Bras. 2019, 54, e00276. [CrossRef] 
23. Zaheer, M.S.; Raza, M.A.S.; Saleem, M.F.; Khan, I.H.; Ahmad, S.; Iqbal, R.; Manevski, K. Investigating the effect of Azospirillum brasilense and Rhizobium pisi on agronomic traits of wheat (Triticum aestivum L.). Arch. Agron. Soil Sci. 2019, 65, 1554-1564. [CrossRef]

24. Zaheer, M.S.; Raza, M.A.S.; Saleem, M.F.; Erinle, K.O.; Iqbal, R.; Ahmad, S. Effect of rhizobacteria and cytokinins application on wheat growth and yield under normal vs drought conditions. Commun. Soil Sci. Plan. 2019, 50, 2521-2533. [CrossRef]

25. Galindo, F.S.; Buzetti, S.; Rodrigues, W.L.; Boleta, E.H.M.; Silva, V.M.; Tavanti, R.F.R.; Fernandes, G.C.; Biagini, A.L.C.; Rosa, P.A.L.; Filho, M.C.M.T. Inoculation of Azospirillum brasilense associated with silicon as a liming source to improve nitrogen fertilization in wheat crops. Sci. Rep. 2020, 10, 6160. [CrossRef] [PubMed]

26. Galindo, F.S.; Filho, M.C.M.T.; Buzetti, S.; Santini, J.M.K.; Boleta, E.H.M.; Rodrigues, W.L. Macronutrient accumulation in wheat crop (Triticum aestivum L.) with Azospirillum brasilense associated with nitrogen doses and sources. J. Plant Nutr. 2020, 43, 1057-1069. [CrossRef]

27. Galindo, F.S.; Filho, M.C.M.T.; Buzetti, S.; Pagliari, P.H.; Santini, J.M.K. Can NBPT urease inhibitor in combination with Azospirillum brasilense inoculation improve wheat development? Nutr. Cycl. Agroecosys. 2020, 117, 131-143. [CrossRef]

28. Juknevičius, D.; Kriaučiūnienè, A.; Jasinskas, A.; Šarauskis, E. Analysis of changes in soil organic carbon, energy consumption and environmental impact using bio-products in the production of winter wheat and oilseed Rape. Sustainability 2020, $12,8246$. [CrossRef]

29. IUSS Working Group WRB. World Reference Base for Soil Resources 2014. In International Soil Classification System for Naming Soils and Creating Legends for Soil Maps; FAO: Rome, Italy, 2015.

30. PKN. PN-ISO 10390:1997. Soil Quality—pH Determination; Polish Committee for Standardization: Warsaw, Poland, 1997.

31. Regional Agrochemical Station. Research Procedure of the Regional Agrochemical Station in Warsaw, 2009; Regional Agrochemical Station: Warsaw, Poland, 2009.

32. Regional Agrochemical Station. Research Procedure of the Regional Agrochemical Station in Warsaw, 2017; Regional Agrochemical Station: Warsaw, Poland, 2017.

33. PKN. Polish Standard PN-R-04023:1996. Agro-Chemical Analysis of Soil-Determination of Available Phosphorus. Content in Mineral Soils; Polish Committee for Standardization: Warsaw, Poland, 1996.

34. PKN. Polish Standard PN-R-04022:1996/Az1:2002. Agro-Chemical Analysis of Soil-Determination of Available Potassium Content in Mineral Soils; Polish Committee for Standardization: Warsaw, Poland, 1996.

35. PKN. Polish Standard PN-R-04020:1994/Az1:2004. Agro-Chemical Analysis of Soil_Determination of Available Magnesium Content in Mineral Soils; Polish Committee for Standardization: Warsaw, Poland, 1994.

36. PKN. Polish Standard PN-93/R-04018. Agro-Chemical Analysis of Soil. Determination of Available Boron; Polish Committee for Standardization: Warsaw, Poland, 1993.

37. PKN. Polish Standard PN-92/R-04017. Agro-Chemical Analysis of Soil. Determination of Available Copper; Polish Committee for Standardization: Warsaw, Poland, 1992.

38. PKN. Polish Standard PN-R-04021: 1994. Agro-Chemical Analysis of Soil. Determination of Available Iron; Polish Committee for Standardization: Warsaw, Poland, 1994.

39. PKN. Polish Standard PN-93/R-04019. Agro-Chemical Analysis of Soil. Determination of Available Manganese; Polish Committee for Standardization: Warsaw, Poland, 1993.

40. PKN. Polish Standard PN-92/R-04016. Agro-Chemical Analysis of Soil. Determination of Available Zinc; Polish Committee for Standardization: Warsaw, Poland, 1992.

41. AACC International. Approved Methods of the American Association of Cereal Chemists, 11th ed.; The Association AACC International: St. Paul, MN, USA, 2015.

42. ISO 3093:2009. Wheat, Rye and Their Flours, Durum Wheat and Durum Wheat Semolina-Determination of the Falling Number According to Hagberg-Perten; International Organization for Standardization: Geneva, Switzerland, 2009.

43. PKN. Polish Industry Standard BN-69 9131-02. Cereals Grain. Determination of Grain Uniformity; Polish Committee for Standardization: Warsaw, Poland, 1969.

44. PKN. Polish Standard PN-EN ISO 520. Cereals and Pulses-Determination of the Mass 1000 Grains; Polish Committee for Standardization: Warsaw, Poland, 2010.

45. Salantur, A.; Ozturk, A.; Akten, S. Growth and yield response of spring wheat (Triticum aestivum L.) to inoculation with rhizobacteria. Plant Soil Environ. 2011, 52, 111-118. [CrossRef]

46. Kumar, V.; Behl, R.K.; Narula, N. Establishment of phosphate-solubilizing strains of Azotobacter Chroococcum in the rhizosphere and their effect on wheat cultivars under green house conditions. Microbiol. Res. 2001, 156, 87-93. [CrossRef]

47. Dal Cortivo, C.; Ferrari, M.; Visioli, G.; Lauro, M.; Fornasier, F.; Barion, G.; Panozzo, A.; Vamerali, T. Effects of seed-applied biofertilizers on rhizosphere biodiversity and growth of common wheat (Triticum aestivum L.) in the field. Front. Plant Sci. 2020 11, 72. [CrossRef]

48. Alves, C.J.; Arf, O.; Ramos, A.F.; Galindo, F.S.; Nogueira, L.M.; Rodrigues, R.A.F. Irrigated wheat subjected to inoculation with Azospirillum brasilense and nitrogen doses as top-dressing. R. Bras. Eng. Agr. Amb. 2017, 21, 537-542. [CrossRef]

49. Galindo, F.S.; Filho, M.C.M.T.; Buzetti, S.; Santini, J.M.K.; Alves, C.J.; Ludkiewicz, M.G.Z. Wheat yield in the Cerrado as affected by nitrogen fertilization and inoculation with Azospirillum brasilense. Pesqui. Agropecu. Bras. 2017, 52, 794-805. [CrossRef] 
50. Fahsi, N.; Mahdi, I.; Mesfioui, A.; Biskri, L.; Allaoui, A. Plant Growth-Promoting Rhizobacteria isolated from the Jujube (Ziziphus lotus) plant enhance wheat growth, Zn uptake, and heavy metal tolerance. Agriculture 2021, 11, 316. [CrossRef]

51. Nagaraju, Y.; Triveni, S.; Vijaya Gopal, A.; Thirumal, G.; Prasanna Kumar, B.; Jhansi, P. In vitro Screening of Zn solubilizing and Potassium releasing isolates for Plant Growth Promoting (PGP) characters. Bull. Environ. Pharmacol. Life Sci. $2017,6,590-597$.

52. Rahman, C.H.; Ahcene, B.; Miloud, B.; Rachid, D. Screening and characterization of plant growth promoting traits of phosphate solubilizing bacteria isolated from wheat rhizosphere of Algerian saline soil. Malays. J. Microbiol. 2017, 13, $124-131$.

53. Mukhtar, S.; Shahid, I.; Mehnaz, S.; Malik, K.A. Assessment of two carrier materials for phosphate solubilizing biofertilizers and their effect on growth of wheat (Triticum aestivum L.). Microbiol. Res. 2017, 205, 107-117. [CrossRef]

54. Boubekri, K.; Soumare, A.; Mardad, I.; Lyamlouli, K.; Hafidi, M.; Ouhdouch, Y.; Kouisni, L. The Screening of potassium- and phosphate-solubilizing actinobacteria and the assessment of their ability to promote wheat growth parameters. Microorganisms 2021, 9, 470. [CrossRef] [PubMed]

55. Abaid-Ullah, M.; Nadeem, M.; Hassan, M.; Ganter, J.; Muhammad, B.; Nawaz, K.; Shah, A.S.; Hafeez, F.Y. Plant Growth Promoting Rhizobacteria: An alternate way to improve yield and quality of wheat (Triticum aestivum). Int. J. Agric. Biol. $2015,17,51-60$.

56. Timmusk, S.; Abd El-Daim, I.A.; Copolovici, L.; Tanilas, T.; Kännaste, A.; Behers, L.; Nevo, E.; Seisenbaeva, G.; Stenström, E.; Niinemets, Ü. Drought-tolerance of wheat improved by rhizosphere bacteria from harsh environments: Enhanced biomass production and reduced emissions of stress volatiles. PLOS ONE 2014, 9, e96086. [CrossRef]

57. Ilyas, N.; Mumtaz, K.; Akhtar, N.; Yasmin, H.; Sayyed, R.Z.; Khan, W.; El Enshasy, H.A.; Dailin, D.J.; Elsayed, E.A.; Ali, Z. Exopolysaccharides producing bacteria for the amelioration of drought stress in wheat. Sustainability 2020, 12, 8876. [CrossRef]

58. Barnawal, D.; Bharti, N.; Pandey, S.S.; Pandey, A.; Chanotiya, C.S.; Kalra, A. Plant growth-promoting rhizobacteria enhance wheat salt and drought stress tolerance by altering endogenous phytohormone levels and TaCTR1/TaDREB2 expression. Physiol. Plant. 2017, 161, 502-514. [CrossRef] [PubMed]

59. Verma, P.; Yadav, A.N.; Khannam, K.S.; Kumar, S.; Saxena, A.K.; Suman, A. Molecular diversity and multifarious plant growth promoting attributes of Bacilli associated with wheat (Triticum aestivum L.) rhizosphere from six diverse agro-ecological zones of India. J. Basic Microbiol. 2016, 56, 44-58. [CrossRef]

60. Chrouqi, L.; Lahcen, O.; Jadrane, I.; Koussa, T.; Alfeddy, M.N. Screening of soil rhizobacteria isolated from wheat plants grown in the Marrakech Region (Morocco, North Africa) for plant growth promoting activities. JMES 2017, 8, 3382-3390.

61. Bharti, N.; Pandey, S.S.; Barnawal, D.; Patel, V.K.; Kalra, A. Plant growth promoting rhizobacteria Dietzia natronolimnaea modulates the expression of stress responsive genes providing protection of wheat from salinity stress. Sci. Rep. 2016, 6, 34768. [CrossRef]

62. Gontia-Mishra, I.; Sapre, S.; Sharma, A.; Tiwari, S. Alleviation of mercury toxicity in wheat by the interaction of mercury-tolerant Plant Growth-Promoting Rhizobacteria. J. Plant Growth Regul. 2016, 35, 1000-1012. [CrossRef]

63. Rana, A.; Saharan, B.; Joshi, M.; Prasanna, R.; Kumar, K.; Nain, L. Identification of multi-trait PGPR isolates and evaluating their potential as inoculants for wheat. Ann. Microbiol. 2011, 61, 893-900. [CrossRef] 